Review Article

\title{
The Use of Essential Oils and Their Isolated Compounds for the Treatment of Oral Candidiasis: A Literature Review
}

\author{
Elba dos Santos Ferreira $\left(\mathbb{D},{ }^{1}\right.$ Pedro Luiz Rosalen, ${ }^{2,3}$ Bruna Benso, ${ }^{3}$ \\ Janaina de Cássia Orlandi Sardi, ${ }^{4}$ Carina Denny ${ }^{D},{ }^{3}$ Simone Alves de Sousa, ${ }^{5}$ \\ Felipe Queiroga Sarmento Guerra, ${ }^{6}$ Edeltrudes de Oliveira Lima, ${ }^{6}$ Irlan Almeida Freires, ${ }^{3}$ \\ and Ricardo Dias de Castro ${ }^{7}$ \\ ${ }^{1}$ Health Sciences Center, Federal University of Paraíba, João Pessoa 58051-970, PB, Brazil \\ ${ }^{2}$ Federal University of Alfenas, Alfenas, MG, Brazil \\ ${ }^{3}$ Department of Physiological Sciences, Piracicaba Dental School, University of Campinas, Piracicaba, SP, Brazil \\ ${ }^{4}$ Federal University of Mato Grosso do Sul, Faculty of Pharmaceutical Sciences, Pioneiros 79070-900, MS, Brazil \\ ${ }^{5}$ Department of Clinical and Social Dentistry, Federal University of Paraíba, Campus I, João Pessoa, PB, Brazil \\ ${ }^{6}$ Pharmaceutical Sciences Department, Health Sciences Center, Federal University of Paraíba, Campus I, João Pessoa, PB, Brazil \\ ${ }^{7}$ Department of Clinical and Social Dentistry, Health Sciences Center, Federal University of Paraíba, João Pessoa, PB, Brazil \\ Correspondence should be addressed to Elba dos Santos Ferreira; elbaferreira99@ltf.ufpb.br
}

Received 8 July 2020; Revised 28 October 2020; Accepted 24 December 2020; Published 8 January 2021

Academic Editor: Mohd Khan

Copyright ( $\odot 2021$ Elba dos Santos Ferreira et al. This is an open access article distributed under the Creative Commons Attribution License, which permits unrestricted use, distribution, and reproduction in any medium, provided the original work is properly cited.

\begin{abstract}
In this literature review, we present the main scientific findings on the antifungal activity of essential oils (EOs) applicable for a new drug formulation to treat oral candidiasis. Seven literature databases were systematically searched for eligible in vitro and clinical trials. Selected articles were screened for biological activity, botanical species, phytochemical composition, study design, and methodological quality. A total of 26 articles were included in the review, of which 21 were in vitro studies and 5 clinical trials. The most promising EOs were obtained from Allium tubeorosum, Cinnamomum cassia, Cinnamomum zeylanicum, and Coriandrum sativum $\mathrm{L}$. Among the phytochemicals, citral and thymol were the most active. Clinical trials indicated that the EOs from Pelargonium graveolens and Zataria multiflora are potentially effective to treat oral candidiasis. Further nonclinical and clinical studies with these EO are warranted to determine their potential use and safety for the treatment of oral candidiasis.
\end{abstract}

\section{Introduction}

Oral candidiasis is an infection caused by Candida spp. which manifests clinically as erythematous, ulcerated, sensitive white lesions, with soft consistency and easy removal, commonly affecting the palate, oral mucosa, tongue, or oropharynx [1]. Due to the opportunistic pathogenicity of yeasts, oral candidiasis is more prevalent in immunocompromised individuals [2].

Yeast colonization of complete dentures occurs mainly due to the strong adhesion of yeast cells to acrylic resin of base materials [1]. Direct adhesion of yeasts onto dental surfaces is a critical pathogenic factor for the onset of dental stomatitis. Yeast cells can co-aggregate with various bacterial species from the oral plaque and integrated into a robust biofilm pellicle on the surface of dentures. Oral biofilms can be considered microbial reservoirs and significantly affect the oral and systemic health of denture users $[1,3]$.

Polyene and azole drugs, such as nystatin and miconazole, respectively, have been commonly prescribed for the treatment of oral candidiasis [2]. However, recent years have seen failures in antifungal therapy due to increasing microbial resistance rates and high drug toxicity, which have altogether contributed to rise the prevalence of morbidity and mortality indicators related to fungal infections [4]. 
This scenario has encouraged the search for novel substances capable of controlling and treating yeast infections while having low toxicity to the host. Some naturally occurring products are considered an important source of new molecules with biological properties, displaying antifungal efficacy comparable or stronger than that of drugs currently available for clinical use. Essential oils (EOs) are a class of natural products with pharmacological properties, which include antimicrobial, antiseptic, anti-inflammatory, and antioxidant activities [5-9]. These compounds are described as a mixture of volatile constituents produced as secondary metabolites by aromatic plants. With the chemical characteristic of lipophilicity, EOs have the ability to interact with fungal cell membranes and lipid structures. Among their mechanisms of action, EO can disrupt the activity of enzymes involved in ergosterol synthesis or complex with membrane ergosterol, thereby creating pores in the membrane and disrupting permeability [10-12]. In addition, EO can affect cell wall biosynthesis, interfere with protein synthesis or cell division, and stimulate the production of reactive oxygen species, causing growth inhibition or cell death $[13,14]$. In this literature review, we present the main scientific findings on the antifungal activity of EO and their isolated phytochemicals on Candida spp. commonly responsible for oral infections. In vitro and clinical (controlled clinical trials in humans) studies were selected and are further discussed in this review.

\section{Materials and Methods}

2.1. Study Question. This literature review was conducted to address the specific question: "Is there scientific evidence to support the use of EO and/or their isolated constituents for the treatment of oral candidiasis or to warrant further nonclinical and clinical research?"

2.2. Search Strategy and Study Selection. The PRISMA guidelines (Transparent Reporting of Systematic Reviews and Meta-Analyses) [15] were followed. Seven databases were systematically searched for studies of experimental oral candidiasis and randomized controlled clinical trials published up to 1 March 2020 (Table 1).

2.3. Eligibility Criteria. A systematic screening of the articles was performed by two independent examiners according to the following inclusion criteria:

(1) Biological activity: clinical effects of an EO-containing formulation on denture stomatitis or oral candidiasis in in vitro or clinical trials. Primary outcome of interest: antifungal activity of the EO and/or isolated constituent based on their MIC (minimum inhibitory concentration). Secondary outcome of interest: reduction in CFUs (colonyforming units) after treatment with the EO-containing formulation leading to remission or cure of infection. Tertiary outcome of interest: cure or reduction in the size and number of erythematous lesions upon treatment with the EO-containing formulation.

(2) Plant material and chemical elucidation: chemically characterized EO and/or their isolated constituents from aromatic plants.

(3) Study design: in vitro studies and phases I, II, III or IV clinical trials. Sample size and study power (at least $80 \%$ ) should be adequate to determine accurate statistical inferences.

(4) Methodological quality: accuracy of methods and outcomes; internal and external validity; for clinical trials-high quality standards.

(5) Language: articles written in English, Spanish, or Portuguese. Examiners agreed that in cases of inconsistence, the final verdict on which articles should be included would be reached by consensus.

2.4. Data Analysis. For in vitro studies, a range of MIC values was used as a parameter to determine the extent of antifungal activity for interstudy comparisons (adapted from [16]). The established scoring criteria for MIC values are shown in Table 2.

Randomized controlled trials of herbal interventions were analyzed based on the CONSORT guidelines [17]. The Jadad scale [18] was used to check study validity and methodological quality (randomization, blinding, and loss of follow-up). Based on these requirements, clinical studies were assigned scores ranging from 0 to 5 , in which a score $<3$ was indicative of poor quality.

\section{Results}

3.1. Search Strategy. Using a previously defined strategy, bibliographic searches were carried out using specific keyword combinations. A total of 395 articles were retrieved, of which 26 were considered eligible and included in the final review (Figure 1). Twenty-one studies with in vitro design and five clinical trials were included and are further discussed.

3.2. In Vitro Antifungal Activity. The antifungal activity of thirty-one EO and four phytochemicals against Candida spp. strains (clinical isolates and reference strains) was analyzed. As shown in Tables 3 and 4, the most promising EOs were obtained from Allium tuberosum, Cinnamomum cassia, Cinnamomum zeylanicum, and Coriandrum sativum. Citral and Thymol were the most active isolated constituents, with MIC values lower than $100 \mu \mathrm{g} / \mathrm{mL}$, indicating very strong antifungal activity (Table 5) [.

\subsection{Randomized Clinical Trials}

3.3.1. Effects of Intervention. According to the pre-established criteria, five clinical studies were included in this review: Pelargonium graveolens, Zataria multiflora, and Melaleuca alternifolia in three formulations. The main methodological characteristics and outcomes of selected 
TABLE 1: Search strategy and bibliographic databases used to retrieve the articles for this systematic review.

\begin{tabular}{|c|c|}
\hline Primary bibliographic sources & $\begin{array}{l}\text { Search strategy (descriptors and combinations } \\
\text { with Boolean operators) }\end{array}$ \\
\hline SciVerse Scopus (since 1995) & $\begin{array}{c}\text { (i) (Essential oil AND oral candidiasis) } \\
\text { (ii) (Oils, volatile, OR essential oil) AND } \\
\text { (oral candidiasis) } \\
\text { (iii) (Oils, volatile, OR essential oil) AND } \\
\text { (denture stomatitis) }\end{array}$ \\
\hline Web of Science (since 1990) & $\begin{array}{l}\text { Filters; article or review and language } \\
\text { (i) (Essential oil AND oral candidiasis) } \\
\text { (ii) (Oils, volatile, OR essential oil) AND } \\
\text { (oral candidiasis) } \\
\text { (iii) (Oils, volatile OR essential oil) AND } \\
\text { (denture stomatitis) }\end{array}$ \\
\hline Medline via Pubmed (since 1966) & $\begin{array}{c}\text { (i) (Essential oil AND oral candidiasis) } \\
\text { (ii) (Oils, volatile OR essential oil) AND } \\
\text { (oral candidiasis) } \\
\text { (iii) (Oils, volatile OR essential oil) AND } \\
\text { (denture stomatitis) }\end{array}$ \\
\hline $\begin{array}{l}\text { SciELO (Scientific Electronic Library Online) (since 1998), LILACS (Latin American } \\
\text { and Caribbean Health sciences Literature) (since 1982), and Cochrane Library }\end{array}$ & $\begin{array}{c}\text { (i) (Essential oil AND oral candidiasis) } \\
\text { (ii) (Oils, volatile OR essential oil) AND } \\
\text { (oral candidiasis) } \\
\text { (iii) (Oils, volatile OR essential oil) AND } \\
\text { (denture stomatitis) } \\
\text { (iv) (Aceite esencial y candidiasis oral) } \\
\text { (v) (EO e candidíase oral) } \\
\text { (vi) (EO e estomatite protética) }\end{array}$ \\
\hline Google Scholar & $\begin{array}{l}\text { (i) Manual searches according to the reference } \\
\text { lists of the articles }\end{array}$ \\
\hline
\end{tabular}

Search strategy and bibliographic databases and keywords.

TABLE 2: Established parameters based on minimum inhibitory concentrations of essential oils or related chemical constituents.

\begin{tabular}{lcc}
\hline MIC range $(\mu \mathrm{g} / \mathrm{mL})$ & Intensity of antifungal activity & \\
\hline$<100$ & Very strong activity & Score \\
$101-500$ & Strong activity & ++++ \\
$501-1000$ & Moderate activity & +++ \\
$1000-2000$ & Weak activity & ++ \\
$>2001$ & No activity & + \\
\hline
\end{tabular}

Source: adapted from Freires et al. [16].

studies are shown in Table 6 and Figure 2. An experimental gel containing Pelargonium graveolens EO healed completely $(34 \%)$ or partially $(56 \%)$ patients with prosthetic stomatitis as compared to those who received only the gel with a placebo. In addition, the gel was effective in reducing the fungal load as well as in decreasing erythema in patients with prosthetic stomatitis as compared to those treated with the placebo. Another experimental gel containing Zataria multiflora EO was also effective in reducing the fungal load in participants' saliva and denture samples as well as $n$ reducing local inflammation.

\section{Discussion}

The main antimicrobial mechanisms of EO and their constituents are associated with their ability to increase cell membrane permeability due to lipophilicity of their molecules, resulting in extravasation of ions and cellular contents and cell lysis [39-41]. In this review, the selected data suggest that some EO and phytochemicals are promising for the treatment of oral candidiasis and warrant further nonclinical, clinical, and toxicological investigation for pharmaceutical purposes [42-44].

Next, a brief summary of the most active EO and isolated compounds will be presented based on in vitro and clinical studies. Information on ethnopharmacological knowledge, biological properties, and chemical composition is further discussed.

4.1. Essential Oils and Phytochemicals with Promising Antifungal Activity against Candida spp. The Allium genus, which belongs to the Amaryllidaceae family, contains approximately 700 species of plants, such as Allium cepa 


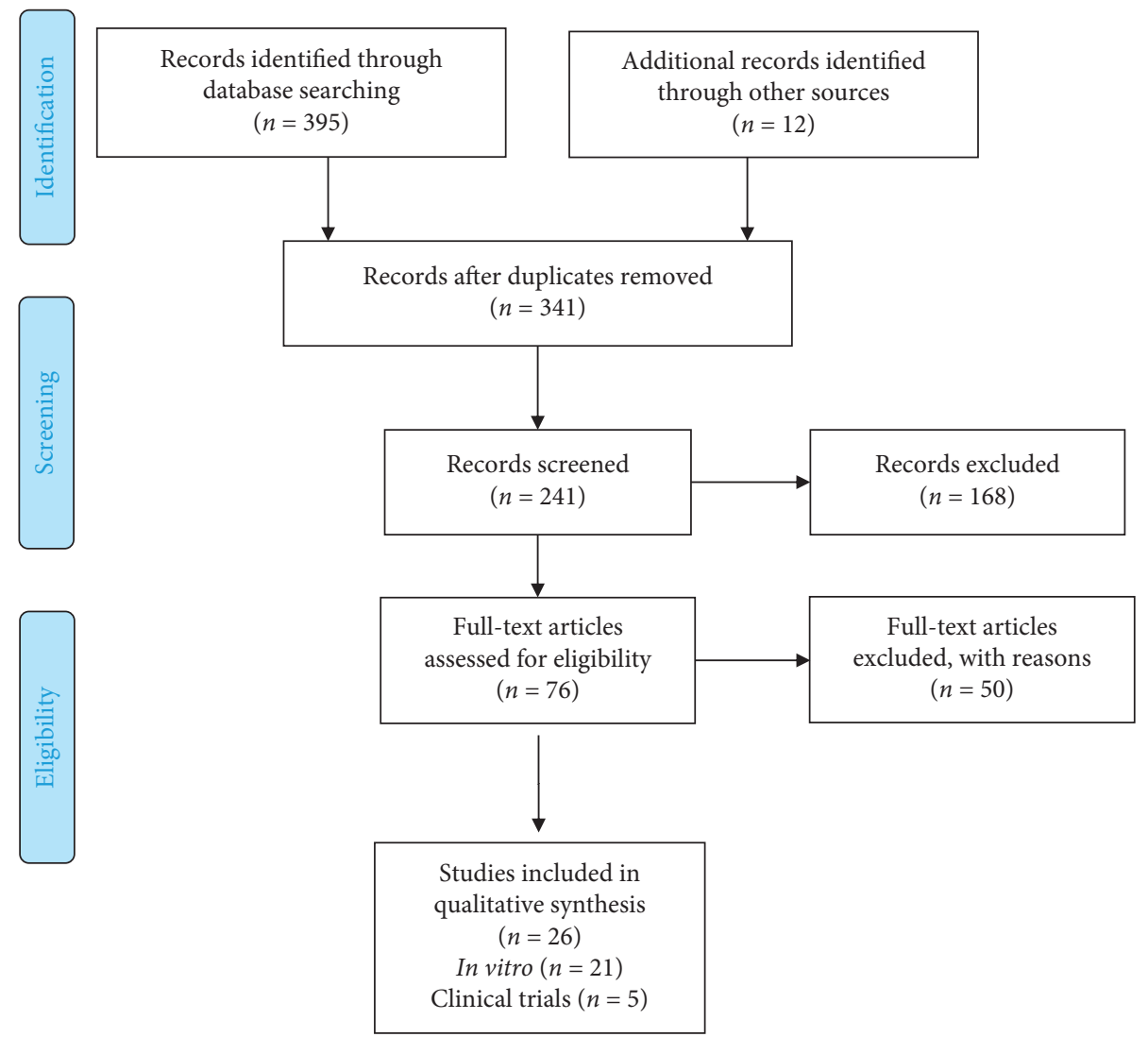

FIGURE 1: Flow diagram of the search strategy comprising the identification of potentially relevant material, preliminary screening (based on PRISMA guidelines) (main categories by which the articles were excluded from the study).

TABLE 3: In vitro antifungal activity of essential oils against Candida albicans strains.

\begin{tabular}{|c|c|c|c|c|c|}
\hline Plant species & Source & Microorganism & $\mathrm{MIC}_{50 \%}(\mu \mathrm{g} / \mathrm{mL})$ & Score MIC & Ref \\
\hline Achillea millefolium & Leaves & C. albicans clinical strain & 625 & ++ & [3] \\
\hline \multirow{2}{*}{ Allium tuberosum Rottl. ex Spreng } & \multirow[t]{2}{*}{ Commercial Source } & C. albicans CBS 562 & 500 & +++ & \multirow{2}{*}{ [19] } \\
\hline & & C. albicans clinical strain & 500 & +++ & \\
\hline \multirow{2}{*}{ Anethum graveolens } & \multirow[t]{2}{*}{ Seeds } & C. albicans ATCC (62342) & $>2001$ & - & \multirow{2}{*}{ [20] } \\
\hline & & Candida albicans clinical strain & $>2001$ & - & \\
\hline Bursera morelensis & Leaves & C. albicans clinical strain & 125 & +++ & {$[21]$} \\
\hline Cinnamomum burmannii & Commercial source & C. albicans ATCC 28366 & 1000 & ++ & [22] \\
\hline \multirow{2}{*}{ Cinnamomum cassia } & Bark & C. albicans ATCC 76485 & 64 & ++++ & \multirow{2}{*}[23]{} \\
\hline & & C. albicans $\mathrm{C} 01-\mathrm{C} 11$ & 64 & ++++ & \\
\hline \multirow[t]{2}{*}{ Cinnamomum zeylanicum } & Commercial source & C. albicans ATCC 76845 & 312.5 & +++ & \multirow[t]{2}{*}[24]{} \\
\hline & Commercial source & C. albicans ATCC 76485 & 312.5 & +++ & \\
\hline \multirow{2}{*}{ Cinnamomum zeylanicum } & & C. albicans ATCC 76645 & 312.5 & +++ & \multirow[t]{2}{*}{ [25] } \\
\hline & & C. albicans clinical strain & 625 & ++ & \\
\hline \multirow{2}{*}{ Cinnamomum zeylanicum Blume } & \multirow[t]{2}{*}{ Commercial source } & C. albicans ATCC 40277 & 312.5 & +++ & \multirow{2}{*}[14]{} \\
\hline & & C. albicans clinical strain & 312.5 & +++ & \\
\hline \multirow{6}{*}{ Cinnamomum zeylanicum Blume } & \multirow[t]{6}{*}{ Commercial source } & C. albicans CBS 562 & 250 & +++ & \multirow{6}{*}[26]{} \\
\hline & & C. albicans ATCC 60193 & 250 & +++ & \\
\hline & & C. albicans ATCC 90029 & 125 & +++ & \\
\hline & & C. albicans LM01 & 250 & +++ & \\
\hline & & C. albicans LM03 & 250 & +++ & \\
\hline & & C. albicans LM04 & 500 & +++ & \\
\hline \multirow{2}{*}{ Coriandrum sativum } & \multirow[t]{2}{*}{ Commercial source } & C. albicans CBS 562 & 15.0 & ++++ & \multirow{2}{*}{ [19] } \\
\hline & & C. albicans clinical strain 3 A5 & 31.0 & ++++ & \\
\hline Coriandrum sativum $L$. & Leaves & C. albicans CBS 562 & 15.6 & ++++ & [27] \\
\hline
\end{tabular}


TABLE 3: Continued.

\begin{tabular}{|c|c|c|c|c|c|}
\hline Plant species & Source & Microorganism & $\mathrm{MIC}_{50 \%}(\mu \mathrm{g} / \mathrm{mL})$ & Score MIC & Ref \\
\hline \multirow{2}{*}{ Cuminum cyminum } & \multirow[t]{2}{*}{ Seeds } & C. albicans ATCC62342 & $>2001$ & - & \multirow{2}{*}[20]{} \\
\hline & & C. albicans clinical strain & $>2001$ & - & \\
\hline Curcuma longa $L$. & Rhizomes & C. albicans Clinical strain & 625 & ++ & [3] \\
\hline Laurus nobilis L. & Commercial source & C. albicans ATCC 60193 & 250 & +++ & {$[28]$} \\
\hline \multirow{2}{*}{ Melaleuca alternifólia } & Commercial source & C. albicans ATCC 289065 & $>2001$ & - & \multirow{2}{*}[29]{} \\
\hline & & C. albicans ATCC 40277 & $>2001$ & - & \\
\hline Melaleuca alternifolia & Commercial source & C. albicans ATCC 18804 & 1950 & + & {$[30]$} \\
\hline Melaleuca alternifolia & Commercial source & C. albicans clinical strain & $>2001$ & - & [31] \\
\hline \multirow{2}{*}{ Pimpinella anisum } & Seeds & C. albicans ATCC 62342 & $>2001$ & - & \multirow{2}{*}{20} \\
\hline & & Candida albicans clinical strain & $>2001$ & - & \\
\hline \multirow{5}{*}{ Ocotea odorifera } & Commercial source & C. albicans ATCC-90028 & $>2001$ & - & \multirow{5}{*}[24]{} \\
\hline & & C. albicans ATCC-76615 & $>2001$ & - & \\
\hline & & C. albicans ATCC-76645 & $>2001$ & - & \\
\hline & & C. albicans ATCC-76485 & $>2001$ & - & \\
\hline & & C. albicans clinical strain & $>2001$ & - & \\
\hline \multirow{2}{*}{ Rosmarinus officinalis } & Commercial source & C. albicans, ATCC 289065 & 562,5 & ++ & \multirow{2}{*}{ [29] } \\
\hline & & C. albicans ATCC 40277 & $<2001$ & - & \\
\hline \multirow{5}{*}{ Rosmarinus officinalis L. } & Commercial source & C. albicans ATCC-90028 & $>2001$ & - & \multirow{5}{*}{ [24] } \\
\hline & & C. albicans ATCC-76615 & $>2001$ & - & \\
\hline & & C. albicans ATCC-76645 & $>2001$ & - & \\
\hline & & C. albicans ATCC-76485 & $>2001$ & - & \\
\hline & & C. albicans clinical strain & $>2001$ & - & \\
\hline \multirow{2}{*}{ Santolina chamaecyparissus } & Commercial source & C. albicans CBS 562 & 1000 & ++ & \multirow{2}{*}[19]{} \\
\hline & & C. albicans clinical strain & $>2001$ & - & \\
\hline Satureja hortensis L. & Leaves & C. albicans Clinical strain & 200 & +++ & {$[32]$} \\
\hline
\end{tabular}

nt (not tested); comparative MIC values $(\mu \mathrm{g} / \mathrm{mL}):(++++)<100 ;(+++) 100$ to $500 ;(++) 501$ to $1000 ;(+)>1001$ to $2000 ;(-)>2001$.

(onion), Allium sativum (garlic), Allium schoenoprasum (chives), and Allium tuberosum (garlic chives). All are important due to their commercial character and nutritional value [45]. Allium tuberosum is a perennial plant that grows in many countries in Asia and whose aerial parts are edible green vegetables common to the Chinese. A. tuberosum has an odor similar to the smell of garlic and other Allium plants due to the presence of sulfur-containing compounds [46].

Several pharmacological activities are attributed to this species, including antidiabetic and hepatoprotective [47], antiparasitic [48], antibacterial [49], and antifungal activities against fungi of the Aspergillus genus [50]. This species has been reported to have strong antifungal activity against Candida parapsilosis isolates and inhibitory effects on biofilm formation [19].

Cinnamomum cassia, popularly known as China cinnamon, is an herb belonging to the Lauraceae family, occurring in several countries such as India, China, Uganda, Vietnam, Bangladesh, and Pakistan. It is intensely aromatic, with a sweet taste and bitter touch. Its peels have been used in different ways, either as a flavoring in various Asian cuisines or in traditional medicine for the treatment of diabetes mellitus and peptic ulcer [51]. The major compound of C. cassia is cinnamaldehyde (75-90\%). Other phytoconstituents, present in trace amounts, include eugenol, benzoic acid, cinnamic acid, salicylic acid, cinnamyl alcohol, and their corresponding esters and aldehydes [52].

C. cassia has been shown to have anti-inflammatory, antioxidant, anticancer, antipyretic, antiangiogenic, larvicidal, and antifungal properties [53]. C. cassia was reportedly active against four Candida spp. strains, namely, C. albicans and C. tropicalis, C. glabrata, and C. krusei, as well as against Aspergillus, Fusarium, and three dermatophyte isolates (Microsporum gypseum, Trichophyton rubrum, and T. mentagraphytes). C. Cassia EO was effective in reducing the number of pseudohyphae in C. albicans cultures, which is considered an important virulence factor [54]. Mouse models and in vitro assays have also proved the antiproliferative activity of $C$. cassia EO against oral candidiasis (C. albicans infection). Cinnamaldehyde was reported as the main compound responsible for the antifungal effects observed in C. cassia EO [55].

Cinnamomum zeylanicum, popularly known as cinnamon, is a very common spice that has been used by different cultures around the world for several centuries. It is obtained from the bark and leaves of trees of the genus Cinnamomum, a perennial tropical plant that has two main varieties, namely, Cinnamomum zeylanicum and Cinnamomum cassia. In addition to its culinary uses, in native Ayurvedic medicine, cinnamon is used as an alternative to treat respiratory, digestive, and gynecological diseases [56]. Four of the main components of the EO obtained from C. zeylanicum bark are trans-cinnamaldehyde, cinnamaldehyde, eugenol, and linalool, which represent $82.5 \%$ of the total EO composition [57]. In vitro and in vivo studies in animals and humans have shown important biological activities attributed to C. zeylanicum EO, such as anti-inflammatory, antimicrobial, reduction of cardiovascular diseases, and increase of cognitive function [58]. Some studies reported that C. zeylanicum EO has antifungal 


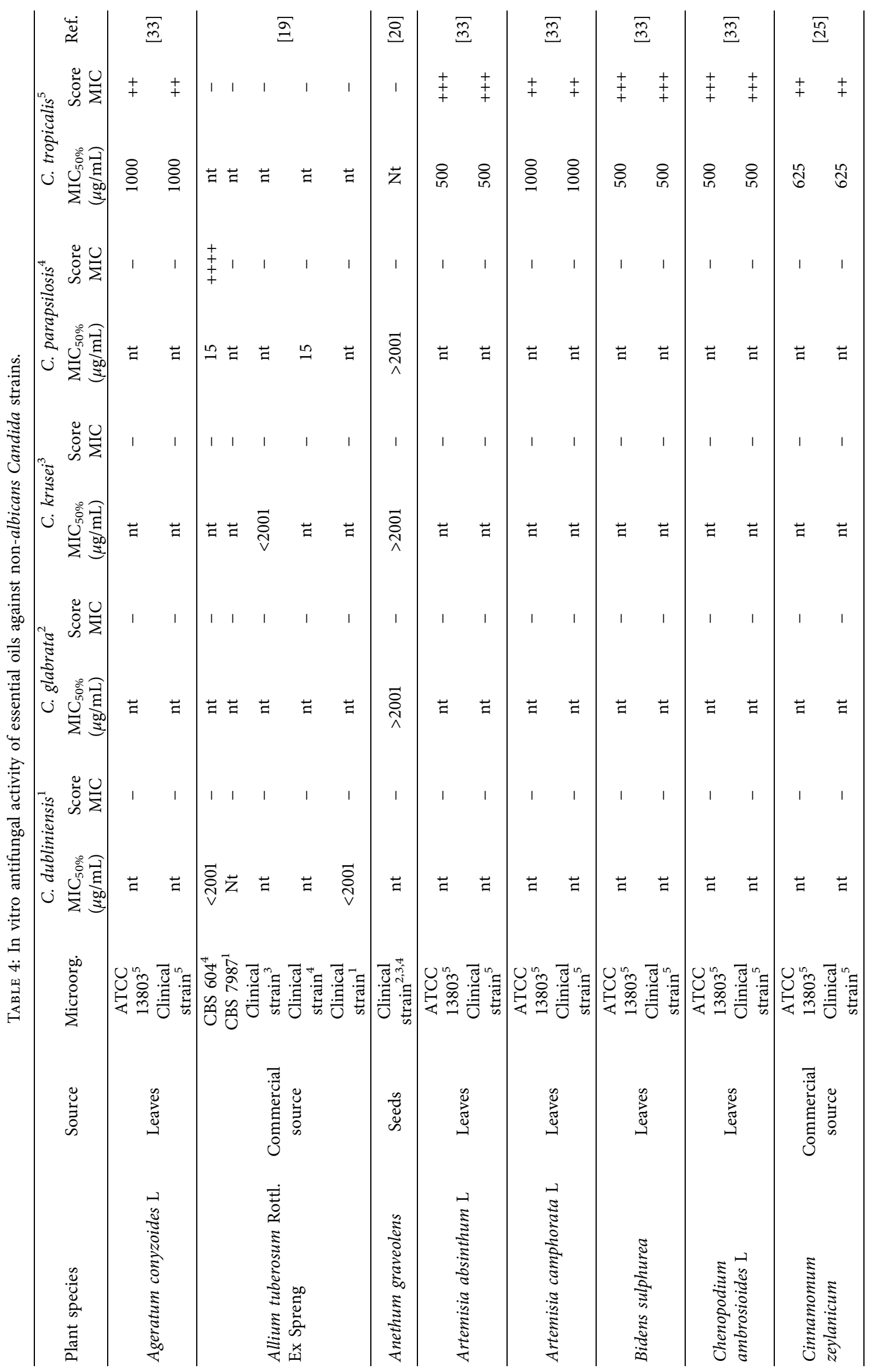




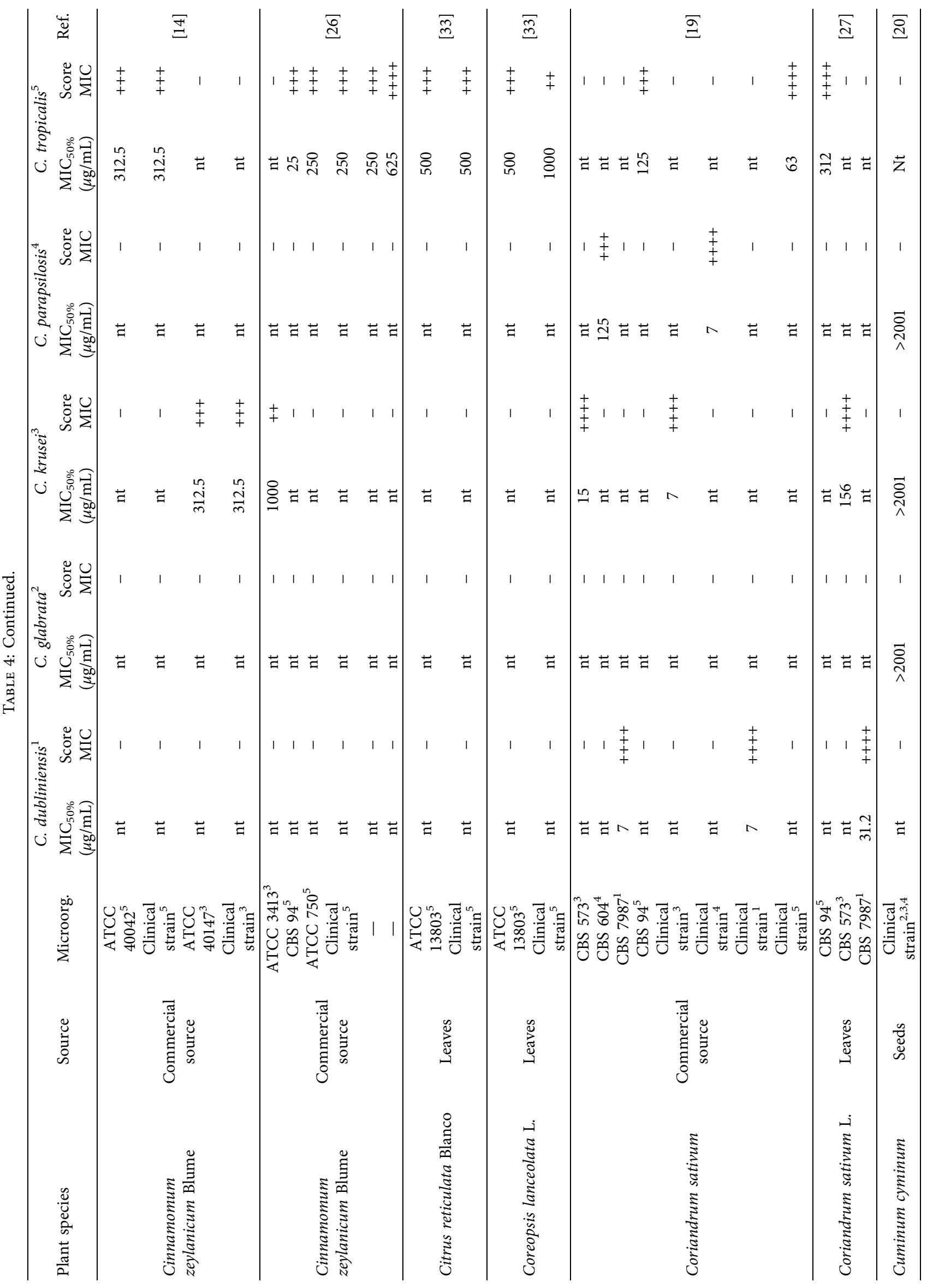




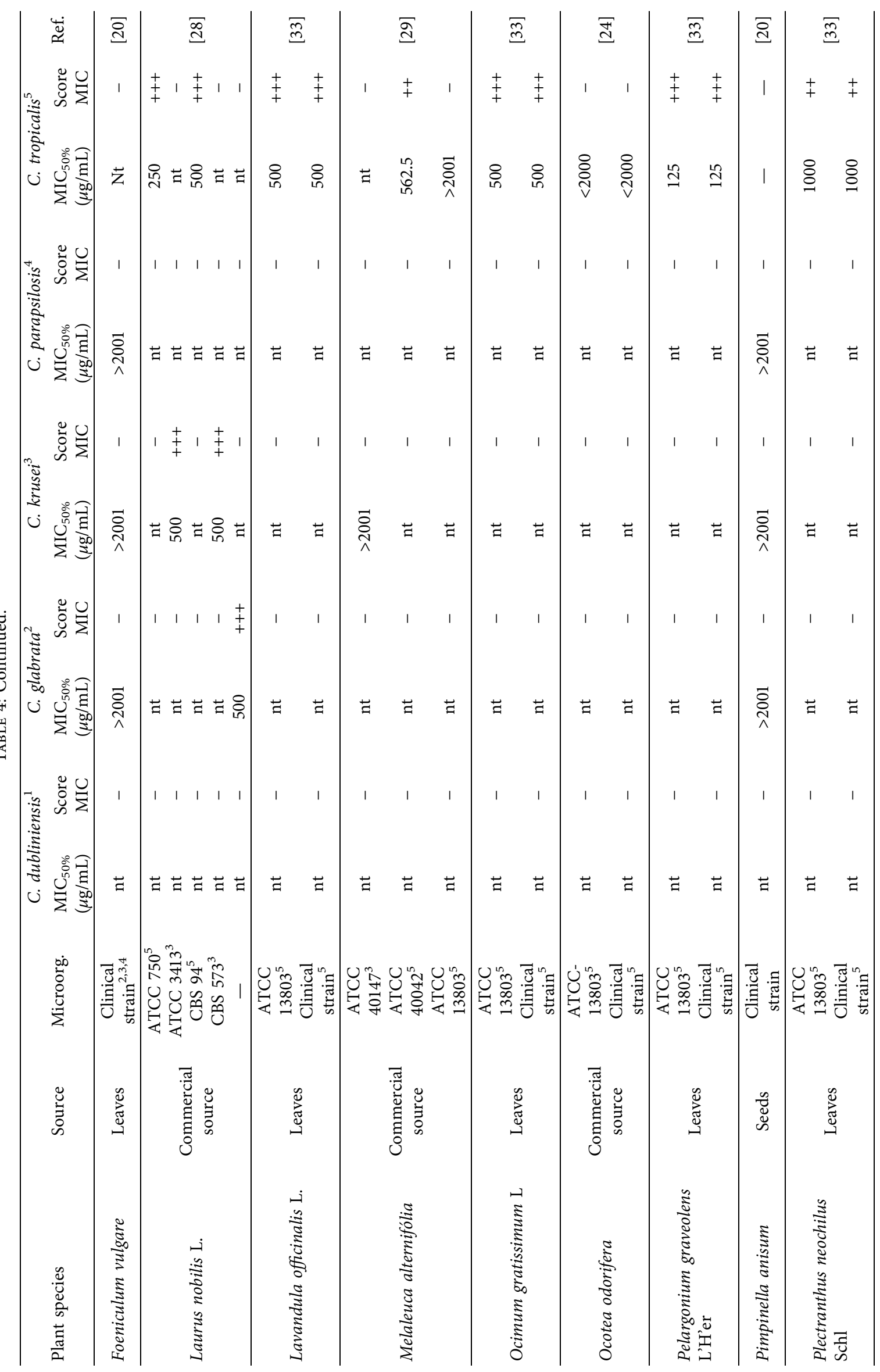




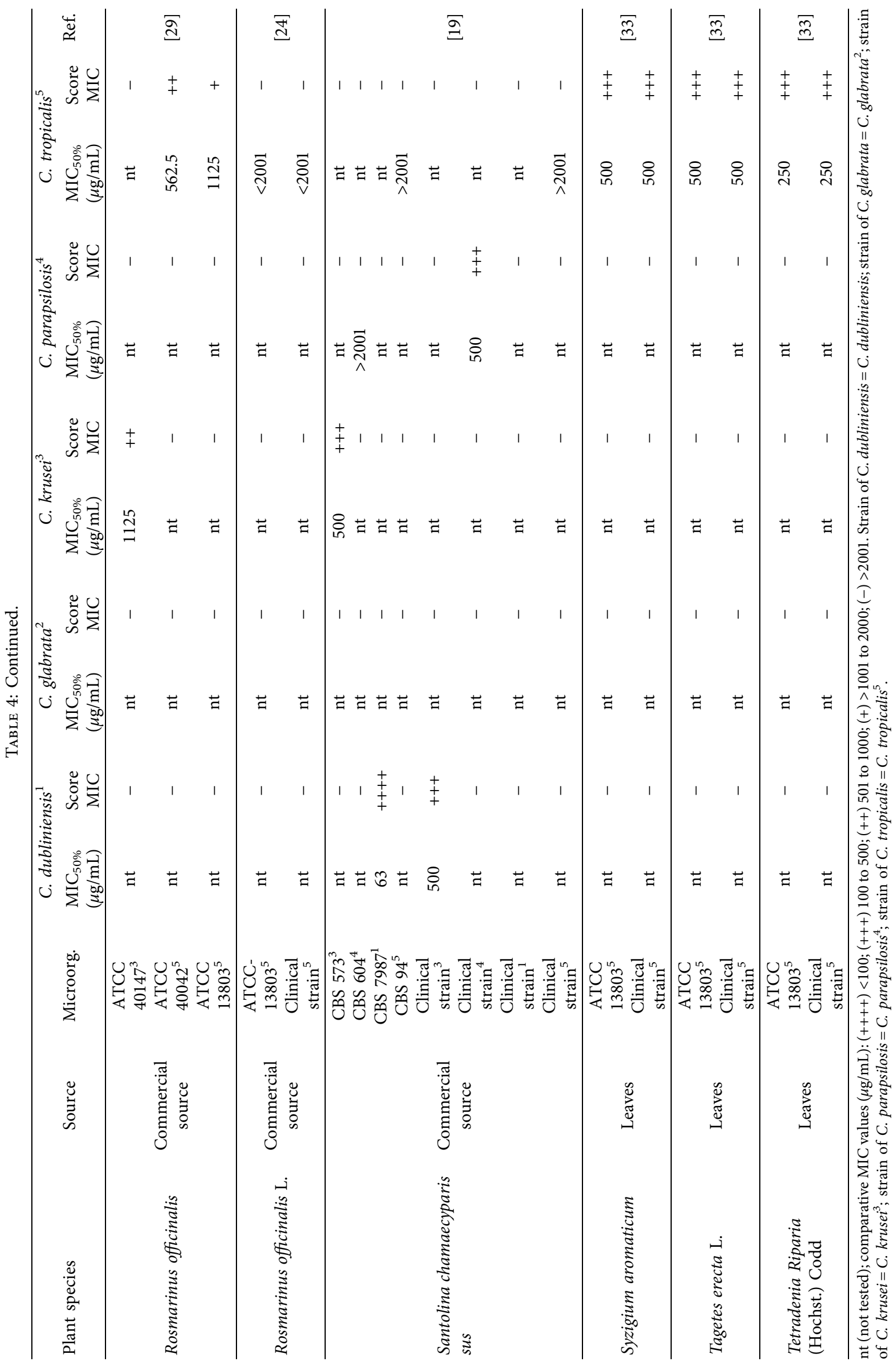


TABLE 5: In vitro antifungal activity of phytoconstituents isolated from essential oils against Candida spp. strains.

\begin{tabular}{|c|c|c|c|c|c|c|}
\hline Plant species & Source & Microorganism & $\mathrm{MIC}(\mu \mathrm{g} / \mathrm{mL})$ & $\operatorname{MFC}(\mu \mathrm{g} / \mathrm{mL})$ & Score MIC & Ref. \\
\hline Citral & Commercial source & $\begin{array}{l}\text { Candida albicans ATCC } 76645 \\
\text { Clinical isolates Candida albicans }\end{array}$ & $\begin{array}{c}32 \\
32-64\end{array}$ & $\begin{array}{c}32 \\
32-64\end{array}$ & $\begin{array}{l}++++ \\
++++\end{array}$ & {$[34]$} \\
\hline Linalol & Commercial source & $\begin{array}{c}\text { C. albicans CA } 032 \\
\text { Candida albicans } 051 \\
\text { Clinical isolate Candida tropicalis } \\
\text { Clinical isolates Candida krusei }\end{array}$ & $\begin{array}{c}2000 \\
1000 \\
500 \\
2000\end{array}$ & $\begin{array}{c}2000 \\
2000 \\
500 \\
2000 \\
\end{array}$ & $\begin{array}{c}+ \\
+ \\
+++ \\
+ \\
+\end{array}$ & {$[35]$} \\
\hline$\alpha$-Pinene & Leaves & Candida albicans clinical strain & 500 & $>2001$ & ++ & {$[21]$} \\
\hline Terpinen-4-ol & Commercial source & Clinical isolates C. albicans & $>2001$ & nt & - & [31] \\
\hline$\gamma$-Terpinene & Leaves & Candida albicans clinical strain & $>2001$ & $>2001$ & - & {$[21]$} \\
\hline Thymol & Commercial source & $\begin{array}{l}\text { C. albicans CBS } 562 \\
\text { C. tropicalis CBS } 94 \\
\text { C. krusei CBS } 573\end{array}$ & $\begin{array}{l}39 \\
78 \\
39\end{array}$ & $\begin{array}{l}39 \\
78 \\
39\end{array}$ & $\begin{array}{l}++++ \\
++++ \\
++++\end{array}$ & {$[36]$} \\
\hline
\end{tabular}

Note: comparative MIC values $(\mu \mathrm{g} / \mathrm{mL}):(++++)<100 ;(+++) 100$ to 500; $(++) 501$ to $1000 ;(+)>1001$ to $2000 ;(-)>2001$.

activity against Candida spp. most likely by disrupting yeast cell wall $[14,24,25]$, which suggests that this EO may be a promising candidate for the treatment of oral candidiasis.

Coriandrum sativum $\mathrm{L}$. is a small plant belonging to the Apiaceae family, popularly known as coriander. Coriander leaves and seeds are widely used in folk medicine as a cholesterol-lowering agent, digestive stimulant, and antihypertensive [11], in addition to its use as a spice in food preparation. The main components present in C. sativum EO are linalool (55.09\%), $\alpha$-pinene (7.49\%), 2,6-octadien-1ol, 3,7-dimethyl-acetate, geraniol (4.83\%), 3-cyclohexene-1methanol, $\alpha, \alpha, 4$-trimethyl- (4.72\%), hexadecanoic acid (2.65\%), acid tetradecanoic (2.49\%), 2 - $\alpha$-pinene $(2.39 \%)$, citronellyl acetate (1.77\%), and undecanal (1.29\%) [59]. Pharmaceutical formulations containing C. sativum also revealed antibacterial [60], antioxidant [61], hepatoprotective, and anticonvulsant properties. C. sativum $\mathrm{EO}$ also showed strong antifungal effects against Candida spp. strains [16].

Citral (3,7-dimethyl-2-6-octadienal) is a racemic mixture composed of geranial (trans-citral, citral A) and neral (cis-citral, citral B) isomers, which are acyclic and monounsaturated aldehydes naturally occurring in many citric fruits, as well as in other herbs or spices [62]. Citral has become a raw material of great importance due to its characteristic lemon aroma and has been used as a flavoring ingredient in the food, perfumery and cosmetic industries [63]. Citral showed fungicidal activity against Candida spp. strains isolated from denture wearers after 2 hours of exposure and caused major morphological changes [34]. Leite et al. [64] demonstrated a strong antifungal activity of citral against $C$. albicans strains via mechanisms other than cell wall biosynthesis or ergosterol complexation. Thus, citral can be considered a promising candidate for the development of novel antifungal leads.

Thymol is a monoterpene found in essential oils extracted from plants belonging to the Lamiaceae family such as the genera Thymus, Ocimum, Origanum, Satureja, Thymbra, and Monarda [65-67]. This molecule is a phytoconstituent with several biological activities described, including anti-inflammatory and antinociceptive [68], local anesthetic [69], and antifungal and antibacterial [70] activities. Thymol has been reported to have strong antifungal activity against strains of the Candida genus, acting on the fungal cell membrane and producing a synergistic effect when used with nystatin to inhibit the growth of these strains [36].

\subsection{Clinical Studies of Essential Oils for the Treatment of Oral} Candidiasis. While numerous studies are carried out to determine the antifungal activity of EO in vitro, only a few formulations reach the clinical stage and even less become a commercial product. As seen in this review, few clinical trials have been carried out to test experimental formulations containing $\mathrm{EO}$ and/or isolated constituents against oral candidiasis. Currently, the most common formulations for the treatment of oral candidiasis are for external use, such as oral solutions, gels, and creams, which are normally safe [71].

Sabzghabaee et al. [37] evaluated the clinical efficacy of a gel containing Pelargonium graveolens EO for the treatment of prosthetic stomatitis. This study presented a low risk of bias for aspects related to randomization and blinding and showed high methodological quality according to Jadad's scale [18]. Another clinical study, conducted by Amanlou et al. [38], showed that Zataria multiflora EO is also effective to treat prosthetic stomatitis. Denture wearers applied the gel containing $0.1 \%$ of $Z$. multiflora $\mathrm{EO}$ four times a day for two weeks. The presence of erythema on the palate surface of participants was significantly reduced as well as CFU counts of yeast strains. Although limitations related to randomization were observed in the study by Amanlou et al. [38], it showed a low risk of bias, which suggests that $Z$. multiflora EO may be a favorable therapeutic alternative for the treatment of prosthetic stomatitis.

Despite the favorable outcomes of EO on oral candidiasis and prosthetic stomatitis reported by the authors of the studies selected in this review, only the studies with $P$. graveolens (popular names: fragrant-leaf geranium-Port., rose geranium-Engl., and geranium-Span.) and Z. multiflora (popular name: thyme of shiraz-Engl.) met high 


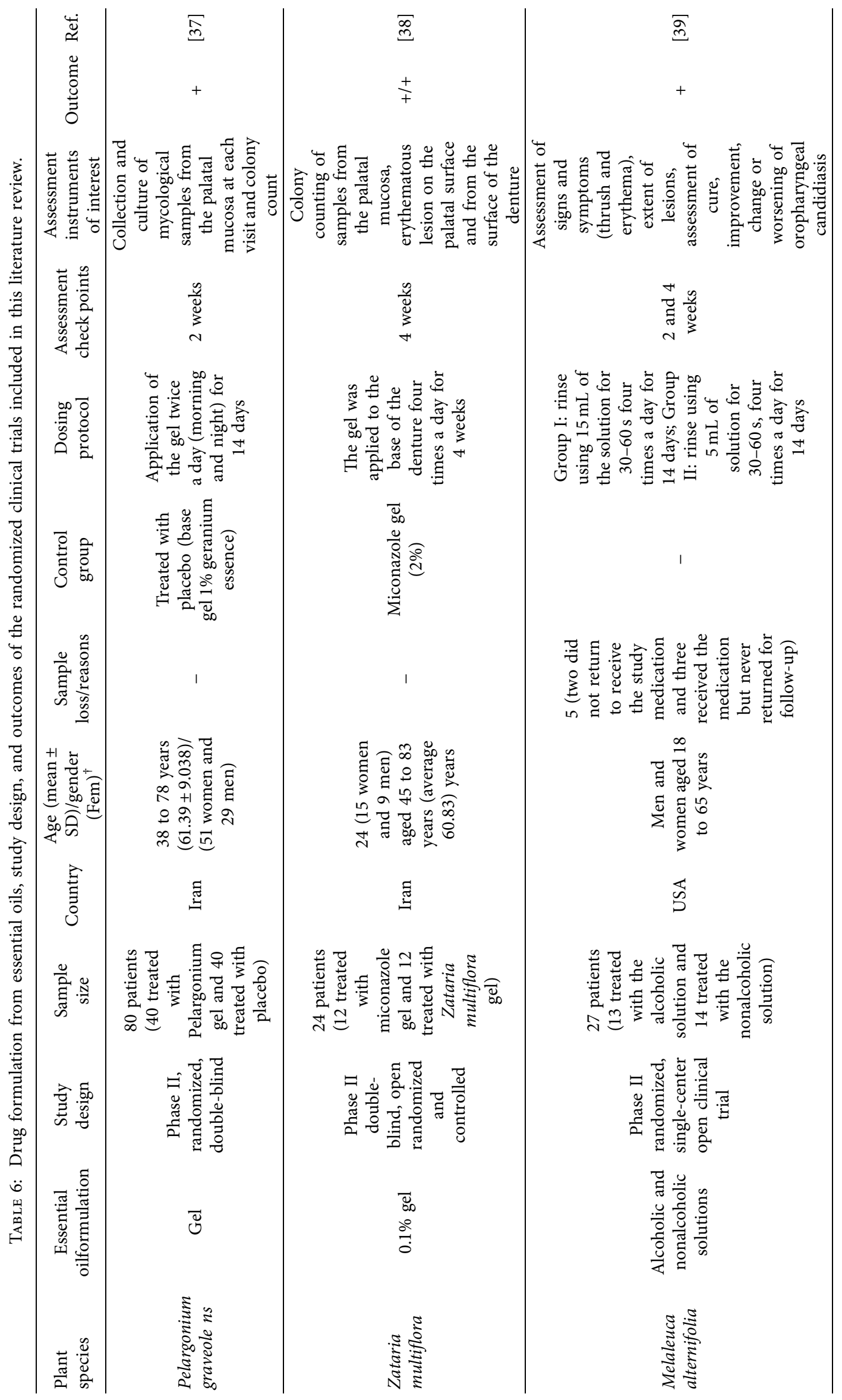




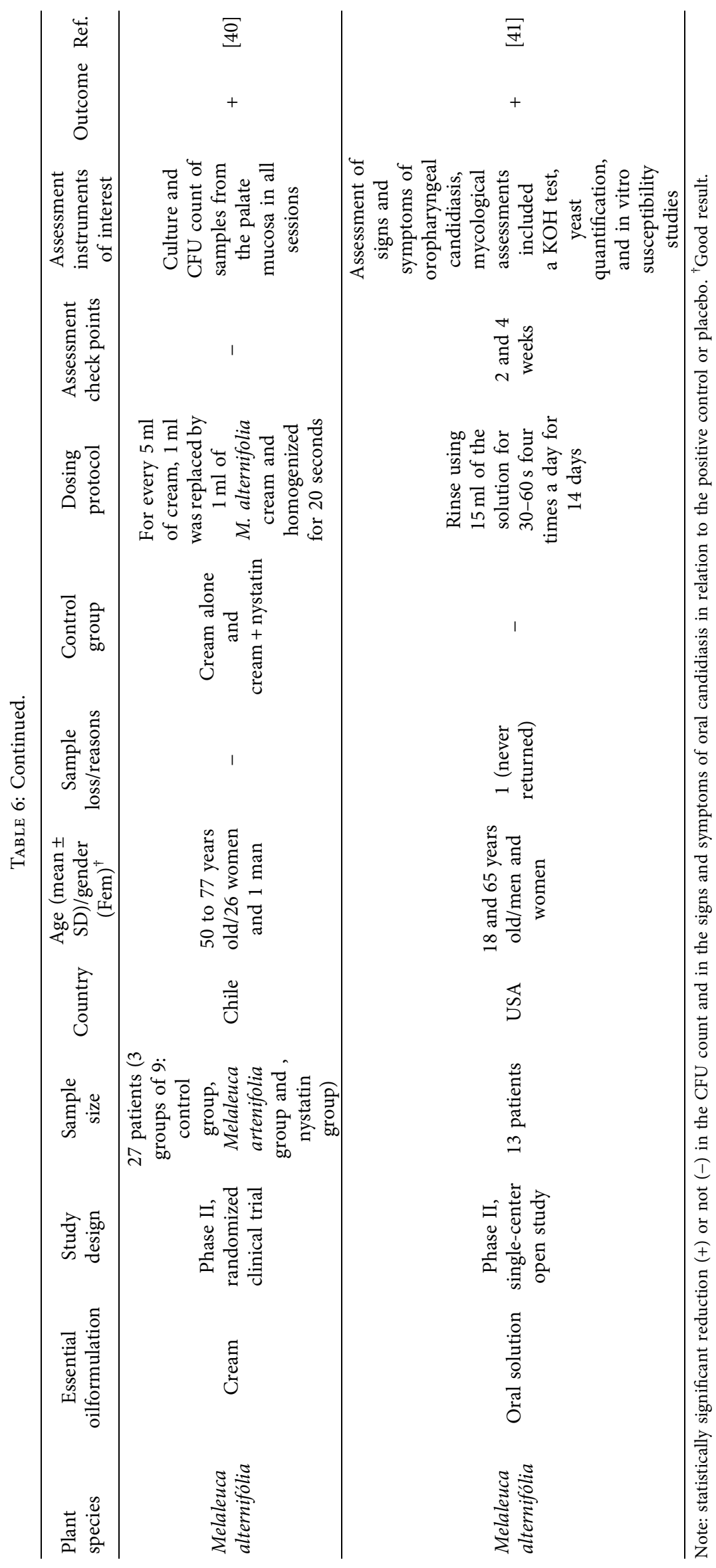




\begin{tabular}{|c|c|c|c|c|c|}
\hline [37] & {$[39]$} & {$[38]$} & {$[40]$} & {$[41]$} & $\begin{array}{c}\text { Random sequence generation } \\
\text { (selection bias) }\end{array}$ \\
\hline 0 & 0 & 0 & 0 & 0 & $\begin{array}{c}\text { Allocation concealment (selection } \\
\text { bias) }\end{array}$ \\
\hline & 0 & 0 & 0 & 0 & $\begin{array}{c}\text { Blinding of participants and } \\
\text { personnel (performance bias) }\end{array}$ \\
\hline & 0 & 0 & 0 & 0 & $\begin{array}{c}\text { Blinding of outcome assessment } \\
\text { (detection bias) }\end{array}$ \\
\hline & 0 & 0 & 0 & 0 & $\begin{array}{c}\text { Incomplete outcome data (attrition } \\
\text { bias) }\end{array}$ \\
\hline & 1 & 0 & 0 & $\begin{array}{c}\text { Selective reporting (reporting bias) } \\
\text { Jadad Scale for assessment of } \\
\text { quality }\end{array}$ \\
\hline
\end{tabular}

Figure 2: Risk-of-bias summary of the clinical trials included in this literature review. Red (-) stands for high risk of bias, green (+) stands for low risk of bias, and yellow (?) stands for unclear risk of bias. Overall, the studies are compliant with the CONSORTguidelines for clinical trials of herbal interventions, showing a low risk of bias.

methodological quality standards. Further research should consider the chemical standardization of these EO and the adoption of appropriate methodological strategies for further clinical testing.

This literature review shows that the most promising EOs were obtained from Allium tubeorosum, Cinnamomum cassia, Cinnamomum zeylanicum, and Coriandrum sativum L. Among the phytochemicals, the citral and the thymol were the most active. The clinical trials selected in this review provided evidence that the EO from Pelargonium graveolens and Zataria multiflora are potentially effective to treat oral candidiasis. Further nonclinical and clinical studies with these EO are warranted to determine their potential use and safety for the treatment of oral candidiasis.

\section{Conflicts of Interest}

The authors declare no conflicts of interest.

\section{Acknowledgments}

This study was financed in part by the Coordenação de Aperfeiçoamento de Pessoal de Nível Superior-Brasil (CAPES)-Finance Code 001.

\section{References}

[1] M. A. Jabra-Rizk, E. F. Kong, C. Tsui et al., "Candida albicans pathogenesis: fitting within the host-microbe damage response framework," Infection and Immunity, vol. 84, no. 10, pp. 2724-2739, 2016.
[2] C. Garcia-Cuesta, M. G. Sarrion-Pérez, and J. V. Bagán, "Current treatment of oral candidiasis: a literature review," Journal of Clinical Experimental Dentistry, vol. 6, no. 5, pp. 576-582, 2014.

[3] D. I. Ribeiro, M. S. Alves, M. G. I. Faria et al., "Determinação da atividade antifúngica dos óleos essenciais de Curcuma longa L. (Zingiberaceae) e de Achillea millefolium (Asteraceae) cultivadas no noroeste do Paraná," Arquivo de Ciências da Saúde, vol. 14, no. 2, pp. 103-109, 2010.

[4] H. Wisplinghoff, J. Ebbers, L. Geurtz et al., "Nosocomial bloodstream infections due to Candida spp. in the USA: species distribution, clinical features and antifungal susceptibilities," International Journal of Antimicrobial Agents, vol. 43, no. 1, pp. 78-81, 2014.

[5] A. Zida, S. Bamba, A. Yacouba, R. Ouedraogo-traore, and R. T. Guiguemdé, "Anti Candida albicans natural products, sources of new antifungal drugs: a review," Journal de Mycologie Medicale, vol. 27, no. 1, pp. 1-19, 2016.

[6] F. Bakkali, S. Averbeck, D. Averbeck, and M. Idaomar, "Biological effects of essential oils-a review," Food and Chemical Toxicology, vol. 46, no. 2, pp. 446-475, 2008.

[7] R. Gyawali and S. A. Ibrahim, "Natural products as antimicrobial agents," Food Control, vol. 46, no. 2, pp. 412-429, 2014.

[8] M. F. B. Morais-Braga, D. L. Sales, J. N. P. Carneiro et al., "Psidium guajava L. and Psidium brownianum Mart ex DC.: chemical composition and anti-Candida effect in association with fluconazole," Microbial Pathogenesis, vol. 95, pp. 200207, 2016.

[9] K. K. A. Santos, E. F. F. Matias, C. E. S. Souza et al., "Anticandida activity of Mentha arvensis and Turnera ulmifolia," Journal of Medicinal Food, vol. 15, no. 3, pp. 322-324, 2012.

[10] N. N. R. Cardoso, C. S. Alviano, A. F. Blank et al., "Synergism effect of the essential oil from Ocimum basilicum var. Maria 
Bonita and its major components with fluconazole and its influence on ergosterol biosynthesis," Evidence-Based Complementary and Alternative Medicine, vol. 2016, Article ID 5647182, 12 pages, 2016.

[11] S. Shreaz, W. A. Wani, J. M. Behbehani et al., "Cinnamaldehyde and its derivatives, a novel class of antifungal agents," Fitoterapia, vol. 112, pp. 116-131, 2016.

[12] K. Rajkowska, A. Nowak, A. Kunicka-Styczyńska, and A. Siadura, "Biological effects of various chemically characterized essential oils: investigation of the mode of action against Candida albicans and hela cells," RSC Advances, vol. 6, no. 99, pp. 97199-97207, 2016.

[13] S. Singh, Z. Fatima, and S. Hameed, "Citronellal-induced disruption of membrane homeostasis in Candida albicans and attenuation of its virulence attributes," Revista da Sociedade Brasileira de Medicina Tropical, vol. 49, no. 4, pp. 465-472, 2016.

[14] R. D. D. Castro and E. O. Lima, "Anti-candida activity and chemical composition of Cinnamomum zeylanicum Blume essential oil," Brazilian Archives of Biology and Technology, vol. 56, no. 5, pp. 749-755, 2013.

[15] A. Liberati, D. G. Altman, J. Tetzlaff et al., "The prisma statement for reporting systematic reviews and meta-analyses of studies that evaluate health care interventions: explanation and elaboration," Plos Medicine, vol. 6, pp. 1-28, 2009.

[16] I. Freires, C. Denny, B. Benso, S. de Alencar, and P. I. Rosalen, "Antibacterial activity of essential oils and their isolated constituents against cariogenic bacteria: a systematic review," Molecules, vol. 20, no. 4, pp. 7329-7358, 2015.

[17] J. J. Gagnier, H. Boon, P. Rochon et al., "Recommendations for reporting randomized controlled trials of herbal interventions: explanation and elaboration," Journal of Clinical Epidemiology, vol. 59, no. 11, pp. 1134-1149, 2006.

[18] A. R. Jadad, R. A. Moore, D. Carroll et al., "Assessing the quality of reports of randomized clinical trials: is blinding necessary?" Controlled Clinical Trials, vol. 17, no. 1, pp. 1-12, 1996.

[19] V. F. Furletti, I. P. Teixeira, G. Obando-Pereda et al., "Action of Coriandrum sativum L. essential oil upon oral Candida albicans biofilm formation," Evidence-Based Complementary and Alternative Medicine, vol. 2011, Article ID 985832, 9 pages, 2011.

[20] J. N. Vieira, C. L. Gonçalves, J. P. V. Villarreal et al., "Chemical composition of essential oils from the Apiaceae family, cytotoxicity, and their antifungal activity in vitro against Candida species from oral cavity," Brazilian Journal of Biology, vol. 79, no. 3, pp. 432-437, 2019.

[21] C. R. Ivera-yañez, L. I. Terrazas, M. Jimenez-Estrada et al., "Anti-Candida activity of Bursera morelensis Ramirez essential oil and two compounds, $\alpha$-Pinene and $\gamma$-Terpinene an in vitro study," Molecules, vol. 5, no. 12, pp. 1-13, 2017.

[22] M. P. Veilleux and D. Grenier, "Determination of the effects of Cinnamon bark fractions on Candida albicans and oral epithelial cells," BMC Complementary Medicine and Therapies, vol. 19, no. 303, pp. 1-12, 2019.

[23] L. Almeida, Y. C. Cavalcanti, R. D. Castro, and E. O. Lima, "Atividade antifúngica e alterações morfológicas induzidas pelo óleo essencial de cinnamomum cassia frente cepas de Candida albicans isoladas de pacientes HIV positivos," Pesquisa Brasileira em Odontopediatria e Clínica Integrada, vol. 12, no. 3, pp. 393-398, 2012.

[24] R. D. Castro and E. O. Lima, "Screening da atividade antifúngica de óleos essenciais sobre cepas de Candida," Pesquisa Brasileira em Odontopediatria e Clínica Integrada, vol. 11, no. 3, pp. 341-345, 2011.
[25] F. Oliveira, L. Andrade, É. de Sousa, and D. P. Sousa, "Antiulcer activity of essential oil constituents," Molecules, vol. 19, no. 5, pp. 5717-5747, 2014.

[26] M. d. L. Rangel, S. G. d. Aquino, J. M. d. Lima, L. R. Castellano, and R. D. d. Castro, "In vitro effect of Cinnamomum zeylanicum blume essential oil on Candida spp. involved in oral infections," Evidence-Based Complementary and Alternative Medicine, vol. 2018, Article ID 4045013, 13 pages, 2018.

[27] I. A. Freires, R. M. Murata, V. F. Furletti et al., "Coriandrum sativum L. (Coriander) essential oil: antifungal activity and mode of action on Candida spp., and molecular targets affected in human whole-genome expression," PLoS One, vol. 9, no. 6, pp. 1-13, 2014.

[28] L. R. Peixoto, P. L. Rosalen, G. L. S. Ferreira et al., "Antifungal activity, mode of action and anti-biofilm effects of Laurus nobilis Linnaeus essential oil against Candida spp." Archives of Oral Biology, vol. 73, pp. 179-185, 2017.

[29] Y. W. Cavalcanti, L. F. D. Almeida, and W. W. N. Padilha, "Atividade antifúngica de três óleos essenciais sobre cepas de Candida," Revista Odontológica Do Brasil Central, vol. 20, no. 52, pp. 197-201, 2011.

[30] V. M. C. Rasteiro, A. C. B. P. Costa, C. F. Araújo et al., "Essential oil of Melaleuca alternifolia for the treatment of oral candidiasis induced in immunosuppressed mouse model," BMC Complementary Alternative Medicine, vol. 14, no. 489, pp. 1-10, 2014.

[31] K. Ninomiya, N. Maruyama, S. Inoue et al., "The essential oil of Melaleuca alternifolia (tea tree oil) and its main component, terpinen-4-ol protect mice from experimental oral candidiasis," Biological and Pharmaceutical Bulletin, vol. 35, no. 489, pp. 861-865, 2012.

[32] A. Sharifzadeh, A. R. Khosravi, and S. Ahmadian, "Chemical composition and antifungal activity of Satureja hortensis L. essentiall oil against planktonic and biofilm growth of Candida albicans isolates from buccal lesions of HIV+ individuals," Microbial Pathogenesis, vol. 96, pp. 1-9, 2016.

[33] C. M. C. Souza, S. A. Pereira Junior, T. d. S. Moraes et al., "Antifungal activity of plant-derived essential oils on Candida tropicalis planktonic and biofilms cells," Medical Mycology, vol. 54, no. 5, pp. 515-523, 2016.

[34] J. C. P. Freire, J. K. d. O. Júnior, D. d. F. Silva, J. P. d. Sousa, F. Q. S. Guerra, and E. de Oliveira Lima, "Antifungal activity of essential oils against Candida albicans strains isolated from users of dental prostheses," Evidence-Based Complementary and Alternative Medicine, vol. 2017, Article ID 7158756, 9 pages, 2017.

[35] I. J. Dias, E. R. I. S. Trajano, R. D. Castro et al., “Antifungal activity of linalool in cases of Candida spp. isolated from individuals with oral candidiasis," Brazilian Journal of Biology, vol. 78, no. 2, pp. 368-374, 2018.

[36] R. D. Castro, T. M. P. A. Souza, L. M. D. Bezerra et al., "Antifungal activity and mode of action of thymol and its synergism with nystatin against Candida species involved with infections in the oral cavity: an in vitro study," $B M C$ Complementary Alternative Medicine, vol. 15, no. 417, pp. 1-7, 2015.

[37] A. M. Sabzghabaee, Z. Shirdare, B. Ebadian, A. Aslani, and A. Ghannadi, "Clinical evaluation of the essential oil of Pelargonium graveolens for the treatment of denture stomatitis," Dental Reseach Journal, vol. 8, no. 1, pp. 105-108, 2011.

[38] M. Amanlou, J. M. Beitollahi, S. Abdollahzadeh, and Z. Tohidast-Ekrad, "Miconazole gel compared with Zataria multiflora Boiss. gel in the treatment of denture stomatitis," Phytotherapy Research, vol. 20, no. 11, pp. 966-969, 2006. 
[39] J. A. Vazquez and A. A. Zawawi, "Efficacy of alcohol-based and alcohol-free melaleuca oral solution for the treatment of fluconazole refractory oropharyngeal candidiasis in patients with AIDS," HIV Clinical Trials, vol. 3, no. 5, pp. 379-385, 2002.

[40] A. Catalán, J. G. Pacheco, A. Martínez, and M. A. Mondaca, "In vitro and in vivo activity of Melaleuca alternifolia mixed with tissue conditioner on Candida albicans," Oral Surgery, Oral Medicine, Oral Pathology, Oral Radiology, and Endodontology, vol. 105, no. 3, pp. 327-332, 2008.

[41] A. Jandourek, J. K. Vaishampayan, and J. A. Vazquez, "Efficacy of melaleuca oral solution for the treatment of fluconazole refractory oral candidiasis in AIDS patients," Aids, vol. 12, no. 9, pp. 1033-1037, 1998.

[42] P. C. Anibal, J. d. C. O. Sardi, I. T. A. Peixoto, J. J. d. C. Moraes, and J. F. Höfling, "Conventional and alternative antifungal therapies to oral candidiasis," Brazilian Journal of Microbiology, vol. 41, no. 4, pp. 824-831, 2010.

[43] J. Vergis, P. Gokulakrishnan, R. K. Agarwal, and A. Kumar, "Essential oils as natural food antimicrobial agents: a review," Critical Reviews in Food Science and Nutrition, vol. 55, no. 10, pp. 1320-1323, 2015.

[44] N. Dagli, R. Dagli, R. Mahmoud, and K. Baroudi, "Essential oils, their therapeutic properties, and implication in dentistry: a review," Journal of International Society of Preventive and Community Dentistry, vol. 5, no. 5, pp. 335-340, 2015.

[45] B. Alizadeh, S. D. Royandazagh, K. M. Khawar, and S. Ozcan, "Micropropagation of garlic chives (Allium tuberosum rottl. Ex spreng) using mesocotyl axis," Journal of Animal and Plant Sciences, vol. 23, no. 2, pp. 543-549, 2013.

[46] J. G. Lombardino and J. A. Lowe, "The role of the medicinal chemist in drug discovery-then and now," Nature Reviews Drug Discovery, vol. 3, no. 10, pp. 853-862, 2004.

[47] R. S. Ika and E. Erfan, "Antioxidant and hepatoprotective activity of garlic chives (Allium tuberosum) ethanolic extract on doxorubicin-induced liver injured rats," International Journal Pharma Medicine and Biological Science, vol. 6, no. 1, pp. 20-23, 2017.

[48] T. Angayarkanni, R. Dhivya, and A. S. Santny, "Phytochemical screening, antioxidant activity and antimicrobial activity of Allium tuberosum," World Journal Pharmaceutical Reseach, vol. 6, no. 16, pp. 991-1004, 2017.

[49] D. Kocevski, M. Du, J. Kan, C. Jing, I. Lacanin, and H. Pavlovic, "Antifungal effect of Allium tuberosum, Cinnamomum cassia, and Pogostemon cablin essential oils and their components against sporulation of Aspergillus species," Journal of Food Science, vol. 78, no. 5, pp. 731-737, 2013.

[50] H. Yong-hong, M. Zhen-chuan, and X. Bing-yan, "Chinese leek (Allium tuberosum Rottler ex Sprengel) reduced disease symptom caused by root-knot nematode," Journal of Integrative Agriculture, vol. 15, no. 2, pp. 364-372, 2016.

[51] E. Block, "Fifty years of smelling sulfur," Journal of Sulfur Chemistry, vol. 34, no. 1-2, pp. 158-207, 2013.

[52] D. Lopes, R. L. O. Godoy, S. L. Gonçalves, M. Koketsu, and A. M. Oliveira, "Sulphur constituents of the essential oil of nira (Allium tuberosum Rottl.) cultivated in Brazil," Flavour and Fragrance Journal, vol. 12, no. 4, pp. 237-239, 1997.

[53] G. Hu, C. Sheng, R. Mao, Z. Ma, Y. Lu, and D. Wei, "Essential oil composition of Allium tuberosum seed from China," Chemistry of Natural Compounds, vol. 48, no. 6, pp. 10911093, 2013.

[54] S. Kumar, R. Kumari, and S. Mishra, "Pharmacological properties and their medicinal uses of Cinnamomum: a review," Journal of Pharmacy and Pharmacology, vol. 71, no. 12, pp. 1735-1761, 2019.

[55] L.-T. Ng and S.-J. Wu, "Antiproliferative activity of Cinnamomum cassia constituents and effects of pifithrin-alpha on their apoptotic signaling pathways in Hep G2 cells," EvidenceBased Complementary and Alternative Medicine, vol. 2011, Article ID 492148, 6 pages, 2011.

[56] L. S. M. Ooi, Y. Li, S.-L. Kam, H. Wang, E. Y. L. Wong, and V. E. C. Ooi, "Antimicrobial activities of cinnamon oil and cinnamaldehyde from the chinese medicinal herb Cinnamomum cassia Blume," The American Journal of Chinese Medicine, vol. 34, no. 3, pp. 511-522, 2006.

[57] Y. Taguchi, T. Takizawa, H. Ishibashi et al., "Therapeutic effects on murine oral candidiasis by oral administration of cassia (Cinnamomum cassia) preparation," Nippon Ishinkin Gakkai Zasshi, vol. 51, no. 1, pp. 13-21, 2010.

[58] P. Ranasinghe, S. Pigera, G. A. S. Premakumara et al., "Medicinal properties of "true" cinnamon (Cinnamomum zeylanicum): a systematic review," Evidence-Based Complementary and Alternative Medicine, vol. 13, no. 275, pp. 1-10, 2013.

[59] S. Chericoni, J. M. Prieto, P. Iacopini, P. Cioni, and I. Morelli, "In vitro activity of the essential oil of Cinnamomum zeylanicum and eugenol in peroxynitrite-induced oxidative processes," Journal of Agricultural and Food Chemistry, vol. 53, no. 12, pp. 4762-4765, 2005.

[60] G. K. Jayaprakasha and L. J. M. Rao, "Chemistry, biogenesis, and biological activities of Cinnamomum zeylanicum," Critical Reviews in Food Science and Nutrition, vol. 51, no. 6, pp. 547-562, 2011.

[61] I.-M. Chung, A. Ahmad, E.-H. Kim et al., "Immunotoxicity activity from the essential oils of coriander (Coriandrum sativum) seeds," Immunopharmacology and Immunotoxicology, vol. 34, no. 3, pp. 499-503, 2012.

[62] L. C. d. C. Galvão, V. F. Furletti, S. M. F. Bersan et al., "Antimicrobial activity of essential oils against Streptococcus mutans and their antiproliferative effects," Evidence-Based Complementary and Alternative Medicine, vol. 2012, Article ID 751435, 12 pages, 2012.

[63] S. N. Harsha and K. R. Anilakumar, "In vitro free radical scavenging and DNA damage protective property of Coriandrum sativum L. leaves extract," Journal of Food Science and Technology, vol. 51, no. 8, pp. 1533-1539, 2012.

[64] M. C. A. Leite, A. P. d. B. Bezerra, J. P. d. Sousa, F. Q. S. Guerra, and E. d. O. Lima, "Evaluation of antifungal activity and mechanism of action of citral against Candida albicans," Evidence-Based Complementary and Alternative Medicine, vol. 2014, Article ID 378280, 9 pages, 2014.

[65] M. Licata, T. Tuttolomondo, G. Dugo et al., "Study of quantitative and qualitative variations in essential oils of Sicilian oregano biotypes," Journal of Essential Oil Research, vol. 27, no. 4, pp. 293-306, 2015.

[66] E. Mancini, F. Senatore, D. Del Monte et al., "Studies on chemical composition, antimicrobial and antioxidant activities of five Thymus vulgaris L. essential oils," Molecules, vol. 20, no. 7, pp. 12016-12028, 2015.

[67] A. Sarwar and Z. Latif, "GC-MS characterisation and antibacterial activity evaluation of Nigella sativa oil against diverse strains of Salmonella," Natural Product Research, vol. 29, no. 5, pp. 447-451, 2015.

[68] S. S. Mendes, R. R. Bomfim, H. C. R. Jesus et al., "Evaluation of the analgesic and anti-inflammatory effects of the essential oil of Lippia gracilis leaves," Journal of Ethnopharmacology, vol. 129 , no. 3, pp. 391-397, 2010. 
[69] G. Haeseler, D. Maue, J. Grosskreutz et al., "Voltage-dependent block of neuronal and skeletal muscle sodium channels by thymol and menthol," European Journal of Anaesthesiology, vol. 19, no. 8, pp. 571-579, 2002.

[70] A. Marchese, I. E. Orhan, M. Daglia et al., "Antibacterial and antifungal activities of thymol: a brief review of the literature," Food Chemistry, vol. 210, no. 1, pp. 402-414, 2016.

[71] A. Marques, C. Lima, D. Alviano, C. Alviano, R. Esteves, and M. Kaplan, "Traditional use, chemical composition and antimicrobial activity of Pectis brevipedunculata essential oil: a correlated lemongrass species in Brazil," Emirates Journal of Food and Agriculture, vol. 25, no. 10, pp. 798-808, 2013. 